\title{
Creation of Own Reserves for Own Shares in the Acquisition of Own Shares for Withdrawal by Simplified Procedure under Slovenian Law where the Consideration is Paid in Instalments
}

\section{GREGOR DRNOVŠEK}

\begin{abstract}
During the process of withdrawing own shares, the rules that are relevant, among others, to their acquisition by the company are regulations governing the creation of reserves for own shares. The regulations are clear in cases where the company acquires their own shares simultaneously with the payment of the purchase price. This article will pertain to the proper application of these regulations according to Slovenian law, specifically in cases where the company pays the purchase price for their own shares, which it intends to withdraw after acquisition, in instalments, and acquires their own shares only after paying the last instalment of the purchase price.
\end{abstract}

Keywords: - reserves for own shares $\bullet$ protection of creditors $\bullet$ purchase price paid in instalments $\bullet$ capital maintenance principle $\bullet$ withdrawal of own shares $\bullet$ joint-stock company $\bullet$ balance sheet law $\bullet$

CORRESPONDENCE ADDRESS: Gregor Drnovšek, PhD, Assistant Professor, University of Maribor, Faculty of Law, Mladinska ulica 9, 2000 Maribor, Slovenia; KPMG poslovno svetovanje, d.o.o., Železna cesta 8A, 1000 Ljubljana, e-mail: gregor.drnovsek@kpmg.si.

DOI 10.18690/lexonomica.10.1.21-32.2018ＵDC: 334.722.8:347.7(497.4)

ISSN 1855-7147 Print / 1855-7155 On-line (C) 2018 University of Maribor Press

Available at: http://journals.um.si/index.php/lexonomica. 
G. Drnovšek: Creation of Own Reserves for Own Shares in the Acquisition of Own Shares for Withdrawal by Simplified Procedure under Slovenian Law where the Consideration is Paid in Instalments

\section{$1 \quad$ Introduction 1}

The reduction of share capital via a withdrawal of own shares in a joint-stock company involves two basic types. The distinction between the two is described in the first sentence of Art. 381(1) of the Slovenian Companies Act (CA): ${ }^{2}$ compulsory withdrawal and withdrawal by acquisition. Compulsory withdrawal occurs when the company does not own the affected shares.

Both types of share capital reduction by withdrawal of shares can be carried out under the ordinary procedure, which is governed by regulations on ordinary share capital reduction (Art. 381(2) of the CA), and under a more simplified procedure (Art. 381(3) of the CA). Provisions on the reduction of share capital by withdrawal of shares also govern the protection of shareholders, whereas the protection of creditors is governed by provisions on ordinary share capital reduction (Art. 375 of the CA). Under the simplified procedure, the protection of creditors is governed by Art. 381(5) of the CA. Both types of share capital reduction by withdrawal of shares have the same legal impact for shareholders: the cancellation of shareholders' rights and liabilities.

At the same time, provisions governing the creation of reserves for own shares are relevant when the company is in the process of acquisition of own shares. These regulations are simple to understand in cases where the acquisition of own shares and the payment of the purchase price are simultaneous. This article pertains to situations where the joint-stock company withdraws their own shares under the simplified procedure set out in Art. 381(3) of the CA; however the acquisition process is still ongoing, as the company exercises the option set out in the seventh indent of Art. 247(1) of the CA. Having chosen this type of acquisition of own shares, the company already entered an agreement with shareholders under which the purchase price for own shares will be paid in instalments, whereas the company will acquire all shares only after paying the final instalment of the purchase price. This scenario calls for a correct interpretation of the CA rules governing the obligation of the joint-stock company to create reserves for own shares.

In order to provide the best answer to the question on the correct application of the regulations on creation of reserves for own shares as presented in the above situation, we need to first highlight certain legal characteristics, relevant to the case presented, concerning the acquisition of own shares under the seventh indent of Art. $247(1)^{3}$ of the $\mathrm{CA}$, as well as the subsequent withdrawal of acquired shares under the second indent of Art. $381(3)^{4}$ of the CA. Moreover, the situation calls for a cursory review of certain indisputable assumptions set out in general provisions of balance sheet law (Part I, Chapter 8 of the CA).

A description of the underlying legal basis is provided for in the second chapter of this article. The legal evaluation provided in the third chapter of this article extends to the capital maintenance principle that links provisions on the acquisition and withdrawal of 


\section{LEXONOMICA \\ G. Drnovšek: Creation of Own Reserves for Own Shares in the Acquisition of \\ Own Shares for Withdrawal by Simplified Procedure under Slovenian Law where the Consideration is Paid in Instalments}

own shares relevant to this article with general provisions of balance sheet law governing the creation and reversal of reserves. The fourth chapter provides an analysis of the creation of reserves for own shares in the annual report and annual balance sheet, which will be followed by a closing statement.

\section{$2 \quad$ Legal basis}

While the acquisition of own shares is prohibited in principle, the exception set out in the seventh indent of Art. 247(1) of the CA allows for a joint-stock company to carry out a derivative acquisition of their own shares based on a resolution of the general meeting on the withdrawal of shares in accordance with the provisions on share capital reduction. The wording "on the basis of a resolution of the general meeting to withdraw shares in accordance with the provisions on share capital reduction" points to the application of Arts. 381 through 383 of the CA, thus encompassing the reduction of share capital under the second indent of Art. 381(3) of the CA. The dynamic essential to the scenario considered in this article is that Art. 247(2) of the CA, which includes a special rule on the creation of reserves for own shares, does not apply to the situation set out in the seventh indent of Art. 247(1) of the CA. ${ }^{5}$ On the other hand, the withdrawal of own shares (for which the issue price was paid in full) under the simplified procedure ${ }^{6}$ is permitted only in two instances; if the shares (as set forth by law): (i) are placed at the company's disposal free of charge, or (ii) are debited to the company's distributable profit or statutory or other revenue reserves, if they are allowed to be used for such purposes (Art. 381(3) of the CA). The situation described above refers only to the second instance.

Part I, Chapter 8 of the CA contains inter alia rules on the reporting of the acquisition of own shares when the company is compiling its annual report. These provisions can be summarized into a rule by which the company that acquired own shares during the financial year shall create reserves for own shares and a deductible item for own shares within the category of revenue reserves on the annual balance sheet (Art. 64(5) and (11) of the CA; Art. 65 of the CA). Own shares are not shown on the asset side of the balance sheet (Art. 65 of the CA). The Slovenian Accounting Standards ${ }^{7}$ (SAS), as an extension of general balance sheet law (cf. Art. 54(7) of the CA), does not contain additional special provisions on the reporting of the acquisition of own shares that would be relevant to the scenario considered in this article. In broader terms, the message of provisions of the SAS concerning the situation referred to above is identical to what can be inferred from the law, namely: (i) reserves for own shares and own shares shall be shown under categories of own capital and in appropriate financial statements (cf. SAS 8.6, SAS 20, SAS 23), and (ii) own shares acquired reduce own capital (cf. SAS 8.11, SAS 8.30, SAS Framework - Chapter 2). ${ }^{8}$

We can infer from the legal basis described above that the cited provisions of the law address very similar (and sometimes even identical) categories under balance sheet law. ${ }^{9}$ As shown later in the article, these provisions are part of a broader set of rules that maintain the capital maintenance principle in joint-stock company law, whereby the 
G. Drnovšek: Creation of Own Reserves for Own Shares in the Acquisition of Own Shares for Withdrawal by Simplified Procedure under Slovenian Law where the Consideration is Paid in Instalments

protection of capital is one of the primary (one of two) focal points of regulations governing the acquisition of own shares. The answer to the question on the creation of reserves for own shares (at least in the situation considered in this article) therefore needs to be sought in the correct understanding of these regulations and how they effect the capital maintenance principle. In other words, we need to determine (i) the meaning of the regulation set out in the second sentence of Art. 247(2) of the CA that does not (explicitly) extend to the acquisition of own shares for purposes of their simplified withdrawal under the second indent of Art. 381(3) of the CA, and (ii) what is the legal meaning of the 'acquisition' of own shares under Art. 64(5) of the CA that triggers the obligation to create reserves for own shares in the annual balance sheet.

\section{Rules on acquisition and withdrawal of own shares as a manifestation of the capital maintenance principle}

\subsection{Capital maintenance principle as a broader closed system}

As shown in the above description of the underlying legal basis, there is a link between Art. 247 and Art. 381 of the CA: a legally effective resolution of the general meeting on the withdrawal of shares justifies the company acquiring own shares. However, this is not the only relevant interaction between these provisions; both are part of a broader set of regulations in law by which the capital maintenance principle and capital lock-in principle are manifested in joint-stock company law. The essence of the capital maintenance principle is rooted in Art. 227(1) of the CA by which capital contributions cannot be refunded and cannot bear interest. The joint-stock company capital lock-in principle is reflected in Art. 230(8) of the CA by which only distributable profit may be distributed to the shareholders. In fact, both principles combine to form a comprehensive whole, whereby the capital lock-in is a necessary result and consequence of the correct understanding and extent of the capital maintenance principle. The latter principle protects creditors and, in its ultimate (most far-reaching) extent, signifies in the context of joint-stock company law that shareholders may only be allocated distributable profit and other payments foreseen (allowed) by law (cf. Fleischer, 2015: 857-858; Wiesner, 2007: 149; Drnovšek, 2010: 1500; Higher Court Ruling No I Cpg 311/2014 ${ }^{10}$ ). The protection of capital (both in terms of maintaining and providing capital) of a joint-stock company is thus one of the primary focuses of corporate law regarding own shares. These regulations also address the protection and delineation of competences of corporate bodies. For purposes of this article, the relevant provision on maintenance of capital is set out in the second sentence of Art. 247(2) of the CA.

The capital maintenance principle does not only link the provisions of Art. 247 and Art. 381 of the CA, but also general rules of balance sheet law governing the creation and appropriation (reversal) of reserves (cf. Art. 64 of the CA). On the level of balance sheet law, it is the capital maintenance principle that is inter alia manifested by provisions on the creation and appropriation of reserves (cf. Prelič, 2005: 383-386; Drnovšek, 2010: 


\section{LEXONOMICA \\ G. Drnovšek: Creation of Own Reserves for Own Shares in the Acquisition of Own Shares for Withdrawal by Simplified Procedure under Slovenian Law where the Consideration is Paid in Instalments}

1499-1503; Plavšak, 2014: 433-434). These provisions also govern the creation and reversal of reserves for own shares (Art. 64(5) and (5) of the CA).

\subsection{Protection of capital in the acquisition of own shares for consideration}

In order to understand how to properly apply the regulations that effect the capital maintenance principle in cases where the company acquires own shares based on the exception set out in the seventh indent of Art. 247(1) of the CA, we need to first understand the mechanics of the capital maintenance principle in what are essentially the most important cases of admissible acquisition of own shares. In cases set out in the first through third and eighth indent of Art. 247(1) of the CA, the maintenance of capital is directly addressed in the second sentence of Art. 247(2) of the CA (" [...] if a company acquires shares by creating reserves for own shares without reducing its share capital or $[\ldots]$ reserves which may not be used for payments to shareholders [...]"). This provision, which is somewhat awkwardly worded, is the implementation of Art. 21(1)(b) of Directive 2012/30/EU of the European Parliament and of the Council of 25 October 2012 on coordination of safeguards which, for the protection of the interests of members and others, are required by Member States of companies within the meaning of the second paragraph of Art. 54 of the Treaty on the Functioning of the European Union ${ }^{11}$ (TFEU), in respect of the formation of public limited liability companies and the maintenance and alteration of their capital, with a view to making such safeguards equivalent ${ }^{12}$ and Art. 60(1)(b) of the current Directive (EU) 2017/1132 of the Parliament and of the Council of 14 June 2017 relating to certain aspects of company law ${ }^{13}$ by which "the acquisitions [...] cannot have the effect of reducing the net assets below the amount referred to in Article $56(1)$ and (2)", i.e. below "the amount of the subscribed capital plus those reserves which may not be distributed under the law or the statutes of the company" (Art. 56(1) of Directive (EU) 2017/1132). ${ }^{14}$

Under national (Slovenian) law (i.e. under Art. 247(2), second sentence, of the CA) this means that the acquisition of own shares for consideration shall not reduce tied-up capital ${ }^{15}$ In other words, the company is allowed to acquire own shares for consideration only by debiting the payment to categories of available capital, i.e. categories that do not fall under the capital maintenance principle and which the company could normally use to increase its distributable profit. ${ }^{16}$ To use the precise language of the law, albeit worded awkwardly, when acquiring own shares, the company needs to be able to create (fictitious) reserves for their own shares, which, under general balance sheet law, can only be debited to components of available capital, i.e. net profit, profit brought forward, statutory reserves, and other revenue reserves (Art. 64(5) of the CA). This arrangement protects the creditors (who are also the target of the capital maintenance principle), as the company may acquire their own shares only by using those sources of assets (and in the same amount) it could otherwise have used to increase its distributable profit (and as payments to shareholders). 
G. Drnovšek: Creation of Own Reserves for Own Shares in the Acquisition of Own Shares for Withdrawal by Simplified Procedure under Slovenian Law where the Consideration is Paid in Instalments

\subsection{Protection of capital in the acquisition of own shares for simplified share withdrawal}

However, the manifestation of the capital maintenance principle and the related protection of creditors outlined above do not apply in cases set out in the seventh indent of Art. 247(1) of the CA that refers to the withdrawal of shares in accordance with the procedure applicable to share capital reduction. The seventh indent of Art. 247(1) of the CA was specifically omitted from the second sentence of Art. 247(2) of the CA. This is no coincidence (or even deficiency), but rather legal rationalism.

In the reduction of share capital by withdrawal of shares, creditors are protected by rules that follow provisions on ordinary reduction of share capital (Art. 381(2) of the CA). These provisions cannot be applied when the company withdraws shares under the simplified procedure, part of which is also the withdrawal under the second indent of Art. $381(3)$ of the CA. The wording of the law in this provision is somewhat awkward ("[ [...] debited to the company's distributable profit or statutory reserves [...]"), however, in the case considered, the provision calls for the company (if it is to meet the primary hypothesis of the rule of law contained in this provision) to acquire own shares in the manner stipulated herein (i.e. the second indent of Art. 381(3) of the CA). More simply put, the company needs to debit the purchase price paid to acquire own shares to its distributable profit, statutory reserves or other revenue reserves (provided these can be used for this purpose). This situation overlaps in all material aspects with the second sentence of Art. 247(2) of the CA. As creditor protection in the case of withdrawal of own shares under the simplified procedure is ensured by designated provisions on the protection of capital (in the present case, the second indent of Art. 381(3) of the CA), having the second sentence of Art. 247(2) of the CA include the situation set out in the seventh indent of Art. 247(1) would denote an unnecessary duplication. Additionally, in case of simplified share withdrawal, creditors are protected by the mandatory allocation of the total nominal amount or Corresponding amount of shares withdrawn to capital reserves (Art. 381(5) of the CA). Thus, even if the share capital is actually reduced, creditors are not deprived of the protective potential available to them in the form of tiedup capital.

We can therefore conclude that in cases where the company is acquiring own shares by resolution of the general meeting under the second indent of Art. 381(3) of the CA, rules on maintenance of capital are adhered to, and thus creditors are protected, namely if the company keeps sufficient distributable profit, statutory reserves or other revenue reserves to which it can debit the consideration paid to acquire own shares. In other words, assets appropriated for the payment of the purchase price for own shares shall be covered by existing and available balance sheet law categories of capital. These assets need to be effectively available and of a sufficient amount. To illustrate, distributable profit is no longer available if the general meeting had previously adopted a resolution on the appropriation of distributable profit, allocating full distributable profit to be paid as dividends. The power to deliberate on whether the company keeps sufficient sources of 


\section{LEXONOMICA \\ G. Drnovšek: Creation of Own Reserves for Own Shares in the Acquisition of Own Shares for Withdrawal by Simplified Procedure under Slovenian Law where the Consideration is Paid in Instalments}

assets is vested into the management, who shall take the deliberation with the necessary diligence. The law does not directly state the obligation to draw up an interim balance sheet, however this is advisable nonetheless, not least because the company will be obligated to enclose the interim balance sheet to the proposal for registration of the share capital reduction in the company register (Art. 23 of the Decree on the registration of companies and other legal entities in the company register). ${ }^{17}$

\section{Creating reserves for own shares in the annual report}

\subsection{Focus of the case}

Parallel to the capital (and creditor) protection system outlined above, which is reflected by the control of whether the purchase price paid for own shares is covered by eligible sources of assets, the law sets forth in Art. 64(5) of the CA the obligation to actually create reserves for own shares when compiling the annual report: "If the company acquires own shares during the financial year, it shall create reserves for own share in its balance sheet for that financial year in the amount of the sums paid to acquire own shares." In order to consistently interpret the rules on the obligation to create reserves for own shares in the present case, we need to first answer the question whether the company is obligated to create reserves for own shares for the financial year in which it had made the payment due to having acquired own shares (paid an instalment of the purchase price) despite not yet becoming the holder of own shares when the payment was made, or whether the obligation to create reserves for own shares under Art. 64(5) of the CA is triggered only after the company actually becomes the holder of shares. In other words, we need to determine the relevant meaning of the term "acquisition" (of own shares) in terms of content and in terms of legal relevance.

\subsection{Purpose of reserves for own shares}

We need to begin the legal evaluation of the presented case by addressing the purpose and function of reserves for own shares. In terms of protection of capital, the acquisition of own shares for consideration denotes a payment to the shareholder disposing of his/her share that is debited to own capital and may be regarded as an alternative to a dividend (cf. Drnovšek, 2010: 1512; Plavšak, 2014: 409; Bezzenberger, 2015: 1082). On the other hand, own shares carry no real value for the company. Moreover, a potential loss would be more detrimental to the company, as the loss will not only impact the company directly, but will also result in a drop in the value of company shares (including own shares). ${ }^{18}$ The purpose of reserves of own shares is to neutralize these risks and to act as a payment barrier. ${ }^{19}$ The amount paid to acquire own shares cannot be paid again due to the creation of reserves. This is clearly indicated also in Art. 63(1)(b) of Directive (EU) 2017/1132 that refers to these reserves as "unavailable for distribution." However, these reserves for own shares are only effective in performing their protective function described above if own shares are shown on the asset side of the balance sheet. If own shares are not included 
LEXONOMICA

G. Drnovšek: Creation of Own Reserves for Own Shares in the Acquisition of Own Shares for Withdrawal by Simplified Procedure under Slovenian Law where the Consideration is Paid in Instalments

among the assets shown in the balance sheet, reserves for own shares are obsolete (cf. Samec, 2009: 593; Reiner, 2013: $§ 272$, para 24). ${ }^{20}$

\subsection{Reserves for own shares in the presented case}

Even though own shares are not shown on the asset side of the balance sheet under national law, the CA maintained the institution of reserves for own shares (Art. 64(5) of the CA), despite EU law setting forth a different legal basis. The CA additionally introduced a deductible item for own shares in the revenue reserves categories. Under the CA, own shares are thus shown on the liabilities side of the balance sheet, whereby reserves for own shares shall be created in the amount equal to the liabilities side item. ${ }^{21}$ Own shares are shown as a deductible item with a negative position, whereby the reserves created have a positive position. The result (sum) of items in the balance sheet is therefore shown as zero, which corresponds with the economic effect of the acquisition of own shares for consideration (payments to shareholders debited to own capital) (Plavšak, 2014: 409), shows how otherwise available categories of own capital are paralyzed in the amount paid to acquire own shares (cf. Kocbek, 2014: 821), and further highlights that own shares carry no value for the company.

The question relevant to the case presented is whether creating a deductible item and reserves for own shares in the annual balance sheet presents an additional protective element aimed at maintaining capital. As shown above, the regulations on acquisition of own shares the company will withdraw under the simplified procedure ensure on a standalone basis that the company can acquire own shares only by debiting the payment to sources of assets it could have otherwise used for payments to shareholders, i.e. by debiting the acquisition to sources the capital maintenance principle does not extend to. Distributable profit and other categories of available capital that increase distributable profit and are observed in calculating the amount thereof (Art. 66(5) of the CA) are thus reduced by the amount equal to payments to shareholders. This is why these rules alone ensure the same level of protection as intended by the capital maintenance principle. ${ }^{22}$ For the case presented in this article, the creation of reserves in the annual balance sheet will have no discernible effect and will not contribute to the protection of either capital or the creditors.

This type of legislative intent-based interpretation of the law also aligns with the interpretation of the law under the textualist approach. The wording of the law bases the obligation to create reserves for own shares exclusively on the legal fact of 'acquisition' of own shares, without delineating the point in time when respective (substantive) legal actions arising from the obligatory legal transaction underlying the acquisition of own shares for consideration were effected (Art. 64(5) of the CA). By the 'letter of the law', the company shall "[...] if [it] acquires own shares during the financial year [...] create reserves for own shares [...]." 


\section{LEXONOMICA \\ G. Drnovšek: Creation of Own Reserves for Own Shares in the Acquisition of Own Shares for Withdrawal by Simplified Procedure under Slovenian Law where the Consideration is Paid in Instalments}

\section{$5 \quad$ Conclusion}

When a company acquires own shares for consideration with the intent of withdrawing own shares under the simplified procedure, the consideration for own shares may be debited only to the company's distributable profit and statutory reserves, along with any other revenue reserves that can be used for this purpose. This rule is a manifestation of the capital maintenance principle and is intended as a means of creditor protection. The company shall carry out appropriate control of available sources whenever it makes a payment (instalment). The company needs to create in the annual balance sheet for the year in which it actually acquired own shares (became the holder of own shares) reserves for own shares, and show own shares as a deductible item, provided the company still holds the shares on the balance sheet cut-off date.

We may therefore answer the question posed in the introduction to this article by saying that the company, in the case presented, shall create reserves for own shares for the financial year in which it became the holder of own shares (additionally, the company shall show own shares as a deductible item on the balance sheet), provided it still holds the shares on the balance sheet cut-off date.

\section{Notes}

${ }^{1}$ Opinions of the author do not necessarily reflect the opinions of the employer.

${ }^{2}$ OJ of the Republic of Slovenia, No 42/2006, as amended.

${ }^{3}$ Seventh indent of Art. 247(1) of the CA stipulates as follows: "A company may acquire its own shares only: [...] on the basis of a resolution of the general meeting to withdraw shares in accordance with the provisions on share capital reduction [...]."

${ }^{4}$ Art. 381(3) of the CA stipulates as follows: "The provisions concerning ordinary share capital reduction shall not apply if the shares for which the issue price has been paid in full:

- $\quad$ are placed at the company's disposal free of charge; or

- $\quad$ are debited to the company's distributable profit or statutory or other revenue reserves, if they are allowed to be used for such purposes."

${ }^{5}$ Art. 247(2) of the CA stipulates as follows: "The total amount of shares acquired for the purposes set out in the first three indents and the eighth indent of the preceding paragraph, together with other own shares which are already held by the company, may not exceed 10 per cent of the share capital. Such acquisition of own shares shall only be permitted if a company acquires shares by creating reserves for own shares without reducing its share capital or reserves, prescribed by Law or statute, which may not be used for payments to shareholders and provided that the issue price of shares had been paid in full. In cases from the first, second, fourth, fifth and eight indents of the preceding paragraph, acquisition shall only be permitted if the issue price of shares is paid in full." 6 I.e. under the procedure based on Art. 381(3) through (5) of the CA, the fundamental "simplification" of which is shown in the fact that rules on the protection of creditors, as they are set out in the case of ordinary reduction of share capital, do not apply to the simplified procedure. For details on the protection of creditors in ordinary reduction of share capital, see Drnovšek, 2012. ${ }^{7}$ Slovenian Accounting Standards (2016), OJ of the Republic of Slovenia, No 95/2015, as amended. 
G. Drnovšek: Creation of Own Reserves for Own Shares in the Acquisition of Own Shares for Withdrawal by Simplified Procedure under Slovenian Law where the Consideration is Paid in Instalments

${ }^{8}$ IAS (International accounting standards, as defined under Regulation (EC) No 1606/2002 of the European Parliament and of the Council of 19 July 2002 on the application of international accounting standards (OJ EU L 243, 11. 9. 2002, p. 1-4, as amended), and Commission Regulation (EC) No 1126/2008 of 3 November 2008 adopting certain international accounting standards in accordance with Regulation (EC) No 1606/2002 of the European Parliament and of the Council (OJ EU L 320, 29. 11. 2008, p. 1-481, as amended)) do not envisage the creation of reserves for own shares (IAS 32.33-34 and AG36). The article does not deal with the relation between IAS, CA and SAS.

${ }^{9}$ Mostly categories of own capital, with the exception of distributable profit which is not a capital category, but rather the result of the calculation using the 'formula' set out in Art. 66(5) of the CA, denoting the amount of company assets 'covered' by categories of available capital that can be utilized for distribution as dividends and other purposes for which distributable profit may be appropriated.

${ }^{10}$ Higher Court in Ljubljana, ruling of 23 June 2015, ECLI:SI:VSLJ:2015: I.CPG.311.2014.

${ }^{11}$ OJ EU C 326, 26. 10. 2012, p. 47-390.

${ }^{12}$ OJ EU L 315, 14. 11. 2012, p. 74-97, as amended.

${ }^{13}$ OJ EU L 169, 30. 6. 2017, p. 46-127.

14 Art. 56(2) of Directive (EU) 2017/1132 is not relevant to the situation considered herein, stipulating "Where the uncalled part of the subscribed capital is not included in the assets shown in the balance sheet, that amount shall be deducted from the amount of subscribed capital referred to in paragraph 1."

15 Tied-up capital is primarily composed of share capital, legal reserves and capital reserves. For details on components and legal characteristics of tied-up capital, see Prelič, 2005: 384-386; Drnovšek, 2010: 1499-1500; Plavšak, 2014: 390-392; Drnovšek and Kramar, 2017: 738-740.

${ }^{16}$ For details on the appropriation of respective categories of capital for purposes of creating reserves for own shares, see Drnovšek, 2010: 1513.

${ }^{17}$ OJ of the Republic of Slovenia, No. 43/2007, as amended. Under Art. 23 of the Decree on the registration of companies and other legal entities in the company register, the proposal to register shall be equipped with a "balance sheet showing the source of funding to acquire shares for withdrawal."

${ }^{18}$ For details on own shares as instruments of no value and the danger they represent for the company, see Bezzenberger, 2015: 1081-1082; Reiner, 2013: § 272, para 24.

${ }^{19}$ On the function of reserves in a corporation in general, see Plavšak, 2014: 379.

${ }^{20}$ Cf. Art. 63(1)(b) of Directive (EU) 2017/1132, which sets forth the obligation to create reserves only "if the shares are included among the assets shown in the balance sheet." The IAS do not call for the creation of reserves for own shares. There are opinions that creating reserves for own shares is not allowed under IAS (Reiner, 2013: $§ 272$, para 137).

${ }^{21}$ On the origin of rules of balance sheet law governing the reporting of own shares and reserves for own shares, see Kocbek, 2014: 820-821.

${ }^{22}$ Art. 64 of the CA does not set forth the obligation to create reserves for own shares from sources the company would need to additionally secure (in addition to sources to which the payments were debited) when compiling the annual report. Once the company pays the consideration for own shares, this reduces the source (available categories of capital) on the liabilities side of the balance sheet to which the payment was debited. This very reduction of source of assets is shown (as a rebooking within the category of own capital) as an increase of reserves for own shares, whereby own shares are shown as a deductible item. To illustrate, if the company purchases own shares during the financial year and pays a consideration of EUR 10,000, the source in the annual balance sheet (e.g. other revenue reserves) is reduced by EUR 10,000 while the reserves for own shares are increased by the same amount, and own shares are shown as a negative position item (as a 


\section{LEXONOMICA \\ G. Drnovšek: Creation of Own Reserves for Own Shares in the Acquisition of Own Shares for Withdrawal by Simplified Procedure under Slovenian Law where the Consideration is Paid in Instalments}

deductible item). The company does not reduce the source twice (due to having paid the consideration and, when compiling the annual report, again to create reserves for own shares). See example in Priročnik Zveze RFR, Slovenski računovodski standardi (2016) v praksi z dodanimi Pravili skrbnega računovodenja, 2016: 189.

\section{References}

Drnovšek, G. (2010) Zakonski rezervni sklad delniške družbe, Podjetje in delo, 36(8), pp. 14981536.

Drnovšek, G. (2012) Upnikova pravica do zavarovanja in registrska zapora pri rednem zmanjšanju osnovnega kapitala delniške družbe, Podjetje in delo, 38(8), pp. 1670-1696.

Drnovšek, G., Kramar, M. (2017) Posojilo družbeniku: zakonodajalčev porozni ukrep s pomirljivim zaključkom, Podjetje in delo, 43(5), pp. 735-745.

Kocbek, M., Plavšak, N. et al. (2014) Veliki komentar Zakona o gospodarskih družbah, 2. dopolnjena izdaja z novelami CAA do CAH, 1. knjiga (Ljubljana: IUS Software, GV založba).

Hoffmann-Becking, M., Wiesner, G. et al. (2007) Münchener Handbuch des Gesellschaftsrechts, Band 4, Aktiengesellschaft (München: Verlag C. H. Beck oHG).

Prelič, S. (2005) Temeljno o varovanju interesa upnikov v pravu kapitalskih družb: pomen pravil o vezanem premoženju, Podjetje in delo, 31(2), pp. 379-386.

Prusnik, M., Odar, M., Koželj, S., Bajuk Mušič, A., Čižman, M., Hieng, R., Zupančič, V. (2016) Priročnik Zveze RFR, Slovenski računovodski standardi (2016) v praksi z dodanimi Pravili skrbnega računovodenja (Ljubljana: Zveza računovodij, finančnikov, in revizorjev Slovenije).

Samec Berghaus, N. (2009) Delniške opcije: obligacijski, korporacijski, delovnopravni, insiderski, bilančni in davčni vidiki (Ljubljana: GV založba).

Schmidt, K., Ebke, W. F., Reiner, G. et al. (2013) Münchener Kommentar zum Handelsgesetzbuch, Band 4, Drittes Buch, Handelsbücher, §§ 238-342e HGB, 3. (München: Auflage, Verlag C. H. Beck/Verlag Franz Vahlen).

Schmidt, K., Lutter, M., Fleischer, H., Bezzenberger, T. et al. (2015) Aktiengesetz Kommentar, I. Band (§§ 1-149), 3. neu bearbeitete Auflage (Köln: Verlag Dr. Otto Schmidt KG). 
32 LEXONOMICA 